TITLE:

\title{
Effects of LiBOB on Salt Solubility and BiF3 Electrode Electrochemical Properties in Fluoride Shuttle Batteries
}

$\operatorname{AUTHOR}(\mathrm{S}):$

Celik Kucuk, Asuman

CITATION:

Celik Kucuk, Asuman. Effects of LiBOB on Salt Solubility and BiF3 Electrode Electrochemical Properties in Fluoride Shuttle Batteries. 京都大学化学研究所スーパーコンピュータシステム研究成果報告書 2019, 2018: 71-72

ISSUE DATE:

2019-03

URL:

http://hdl.handle.net/2433/241197

RIGHT: 


\title{
平成 30 年度 京都大学化学研究所 スーパーコンピュータシステム 利用報告書 \\ フッ化物シャトル電池における、塩可溶性の LiBOB の効果と BiF3 電極の電気化学的特性 \\ Effects of LiBOB on Salt Solubility and BiF3 Electrode Electrochemical Properties \\ in Fluoride Shuttle Batteries
}

\author{
京都大学 産官学連携本部 Asuman Celik Kucuk
}

\section{研究成果概要}

Density Functional Theory (DFT) framework, is used as the computational calculation to determining of the ionic interactions between the electrolyte and salt and between the salt and electrode surfaces. Thus, to investigate the molecular structures in the electrolytes of rechargeable batteries, it is favorable to use DFT calculation.

In one of our study, to confirm some interaction in the electrolyte system we applied the DFT calculation. To validate the assumption based on some interaction which improve the fluoride based salt solubility by ion exchange, the change in the total energy by the reaction between the components was calculated by DFT. The most stable structures were determined based on the DFT calculation.

\section{Please find the abstract of the related study and revealed part of DFT calculation as in the following.}

\section{Effects of LiBOB on Salt Solubility and $\mathrm{BiF}_{3}$ Electrode Electrochemical Properties in Fluoride Shuttle Batteries}

\begin{abstract}
Asuman Celik Kucuk ${ }^{a^{*}}$, Taketoshi Minato ${ }^{a}$, Toshiro Yamanakaa , Takeshi Abe $^{b^{*}}$
In this study, lithium bis(oxalato)borate (LiBOB) was used for the first time in a fluoride shuttle battery (FSB) to overcome the solubility problem of fluorine-based salts typically present in organic solvents. For this purpose, tetraglyme (G4) electrolytes containing CsF salt and LiBOB with three different concentrations ( $\mathrm{LiBOB}_{0.06} / \mathrm{CsF} / \mathrm{G} 4$, $\mathrm{LiBOB}_{0.25} / \mathrm{CsF} / \mathrm{G} 4$, and $\mathrm{LiBOB} 0.5 / \mathrm{CsF} / \mathrm{G} 4$ ) were prepared. The effects of LiBOB on the electrochemical compatibility of the bismuth fluoride positive electrode were examined by cyclic voltammetry, charge-discharge tests, and alternating current impedance measurements. The related discharge and charge reactions were confirmed by X-ray diffractometry, whereas Raman spectroscopy was used to detect potential interactios in the various LiBOB/CsF/G4 systems. At the lowest and highest LiBOB concentrations (i.e., in $\mathrm{LiBOB}_{0.06} / \mathrm{CsF} / \mathrm{G} 4$ and $\mathrm{LiBOB}_{0.5} / \mathrm{CsF} / \mathrm{G} 4$, respectively), the electrolyte decomposition was dominant, whereas the intermediate concentration in $\mathrm{LiBOB}_{0.25} / \mathrm{CsF} / \mathrm{G} 4$ was found to be the optimum condition and played a critical role in CsF solubility, allowing a successful fluoride shuttle-based redox reaction.
\end{abstract}

Relevant study:

According to the Raman results, we can assume that the effect of LiBOB in the electrolyte is to enhance the CsF solubility by ion exchange. To validate this assumption, the change in the total energy by the reaction between LiBOB and CsF was calculated by DFT. Their ion-exchange reaction (Equation 3) form CsBOB and LiF as follows. 


$$
\begin{aligned}
& \mathrm{LiBOB}+\mathrm{CsF} \rightarrow \mathrm{CsBOB}+\mathrm{LiF} \\
& \text { Total energy differences }=-0.41 \mathrm{eV}
\end{aligned}
$$

The resulting change of the total energy in the system was estimated as follows:

$$
\begin{gathered}
\text { Total energy differences }= \\
\left(E_{C S B O B}+E_{L i F}\right)-\left(E_{L i B O B}+E_{C S F}\right)^{\prime}
\end{gathered}
$$

where $E_{\angle і B O B}, E_{C S F}, E_{C S B O B}$, and $E_{L i F}$ are the total energies of free $\mathrm{LiBOB}, \mathrm{CsF}, \mathrm{CsBOB}$, and LiF, respectively. According to a previous work, ${ }^{29}$ three sites of $\mathrm{Li}$ and $\mathrm{Cs}$ in $\mathrm{LiBOB}$ and $\mathrm{CSBOB}$, respectively, were considered in the calculations. The most stable structures of $\mathrm{LiBOB}, \mathrm{CsF}, \mathrm{CsBOB}$, and LiF are shown in Chart 1, and the total energy difference calculated from these structures was $-0.41 \mathrm{eV}$. This means that, after the ion-exchange reaction, energetically favorable CsBOB and LiF were formed. On the contrary, G4 is known to strongly form complexes with $\mathrm{Li}^{+}$. Therefore, Equation 4 is likely realized and $\mathrm{F}^{-}$becomes free (Chart 1).
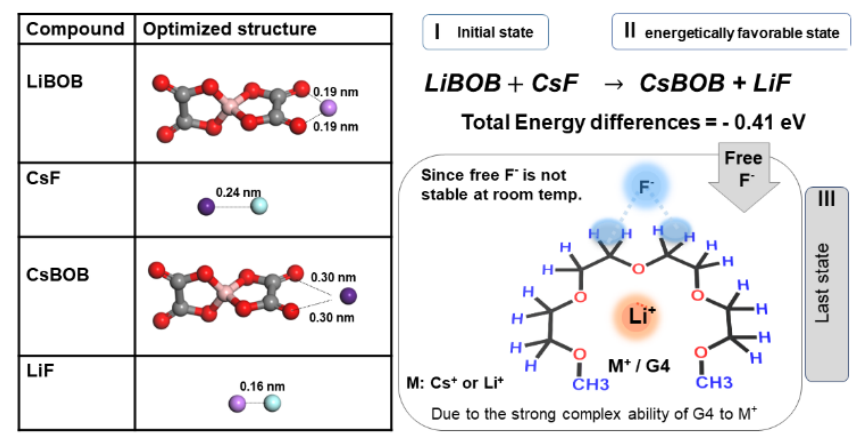

Chart 1 Proposed possible interactions in the $\mathrm{LiBOB}_{0.25} / \mathrm{CsF} / \mathrm{G} 4$ system (LiBOB: lithium bis(oxalato)borate; G4: tetraglyme).

The results obtained from DFT calculations, Raman analysis and ${ }^{19} \mathrm{~F}$ NMR spectroscopic data suggest that the LiBOB addition enhances the solubility of $\mathrm{CSF}$ in $\mathrm{G} 4$ through the interaction between $\mathrm{Cs}^{+}$and $\mathrm{BOB}^{-}$. From that result it can be assumed that free fluoride is stabilized by $\mathrm{M}^{+}$coordinated $\mathrm{G} 4(\mathrm{M} ; \mathrm{Cs}+$ or $\mathrm{Li}+)$. This assumption is also in agreement with the previous report based on the stabilization of complex fluoroanions by glyme- coordinated alkali metal cations. ${ }^{31}$ The authors believe that the interactions occur in the manner of solvent-shared ions pairs rather than contact ion pairs ([M(G4)X], M; Li or Cs, X; F- or BOB-). 